\title{
Sakharov defeated by "odd arithmetic"
}

\section{- Absentees assumed to vote against - Academy relinquishes five seats - Sakharov nominated for Moscow City}

\section{Moscow}

THE failure last week of the enlarged plenum of the Soviet Academy of Sciences to nominate Andrei Sakharov for the forthcoming election of Soviet deputies has caused great surprise and raises the question whether Soviet people, including men and women of science, yet know enough about democracy to practise it.

Sakharov, who had been supported by 60 of the academy's institutes, was not the only disappointed candidate. There were also Roald Sagdeev (supported by more than 25 institutes), Dmitri Likhachev (20 institutes) and such prominent economists (active advocates of perestroika) as Gavriil Popov (15 institutes plus), Nikolai Shmelev (more than 12), Gennadi Lisichkin and Abel Aganbegyan.

Last week's proceedings were an intermediate stage in the election of the 2,250 members of the Congress of People's Deputies, which will meet once a year to decide constitutional matters and will also elect the bi-cameral Supreme Soviet. A total of 75 seats in the chamber has been reserved for representatives of professional associations and societies, of which the academy had 25. But scientists can be elected by other categories of voters. Thus Guri Marchuk, president of the academy, and Yevgeni Velikhov, vice-president, have been nominated as candidates by the Communist Party.

The 17-member electoral commission took two hours to determine the outcome of the voting, by secret ballot. When the results were announced 10 hours after the meeting had begun, those left on the platform and in the hall were equally surprised. The outcome was so unexpected that it seemed like the dénouement of a whodunit.

One strange consequence is that there are now fewer contenders (23) than there were originally vacancies (25) in the academy's intended representation in the Congress of People's Deputies. It had been planned that there would be a meeting in two months at which the contenders would compete, promoting their own platforms. But the first outcome of the plenum would have made meaningless the continuation of the election of the academy's list: the contenders would have had no rivals.

Accordingly, the members of the plenum decided to cut the academy's representation first by two and then by five, a decision endorsed by the praesidium (governing council). The spare seats will be filled by other academic societies and associations.

This development points both to the imperfections of the electoral machinery and to the likelihood that people do not fully appreciate their role in the democratic process.

This election is in two stages. In the first, nominations were made by the members of academy institutes and establishments. People at these meetings participated enthusiastically. Eventually there were more than 130 names on the list of those seeking the academy's nomination. Last week's plenum was intended to prune the list for a second stage at which choices would be made by all members of the academy and institute representatives (one for every 150 workers).

By prior agreement, the plenum did not discuss all the candidates because of lack of time. But it was agreed that the opinions of nominating institutes should be studied carefully, which is significant because the plenum thereby learned of the nominees' scientific and, more importantly, civic qualities. But the outcome of the plenum's procedural discussion was also to ensure a vote 'against' from each of its absent members.

Strictly, this accords with Soviet electoral law, which requires that those elected should receive "the vote of more than half the aggregate number" of those entitled to vote. Last week, 379 people were eligible to attend the enlarged plenum, but 102 of them were absent for various reasons. Whether the academy's election commission ever discussed with the central electoral commission the question of how the absent votes should be dealt with is unknown.

In the event, the qualifying quota was set at 139 votes, but only 190 people took part in the voting, so that the votes of the 89 people who did not were counted as 'against' in each case. Thus each contender had to secure 73 per cent of the votes to be elected. (Yablokov needed only one extra vote, but Sagdeev needed 18 and Sakharov 34.)

Much the same happened at the AllUnion Society of Inventors and Innovators, where the same odd arithmetic meant that only six contenders instead of ten managed to secure qualifying votes. But that council reconvened the plenum to fill the 'vacancies'. Should not the academy have done the same?

One interpretation of the purpose of the academy's plenum is that it was to ensure that the final choice of its 25 representatives would be genuinely competitive, reflecting the will of the scientific community at large. This might reasonably have been done in keeping with certain criteria, such as the number of institutes backing each candidate.

Many of those not nominated had solid backing. It goes without saying that Sakharov was the undisputed leader in the race he eventually lost. But Sakharov is extremely popular outside as well as within the scientific community, with the result that he was nominated, at a meeting on 20 January at the Lebedev Institute where he works, as a candidate for people's deputy from Moscow's Octyabrsky district and, two days later, as a candidate in the election of a deputy to represent the City of Moscow. Yuri Kanin Novosti

\section{Tajikstan struck by earthquake}

\section{London}

THIS week's earthquake in the Soviet republic of Tajikstan, although not as serious as the Armenian catastrophe last month, has inevitably added to growing concern in Tajikstan about seismic safety.

The earthquake is the third in four years. There was a major earthquake in the north of the republic in October 1985 and the collapse of a dam at Sargazan in March 1987. Land and mudslides, such as that which this week buried two villages, are a common accompaniment.

What concerns the population most is the rapid development of hydroelectricity in the republic. A further eight dams are now planned on the River Vaksh, which already has the massive Nurek (305 m) and Rogun $(345 \mathrm{~m})$ dams. People fear that earthquakes may rupture the dams, and even that the dams themselves may trigger earthquakes.

At a meeting two years ago in the Tajikstan capital of Dushanbe, representatives of the Tajikstan Academy of Sciences revealed that the dams had been designed for seismic conditions appropriate to a plain, not a mountainous region, where the effects of seismic disturbances are usually greater. Pravda described the new Ziddin reservoir as "millions of cubic metres of water hanging like the sword of Damocles" over Dushanbe.

Tajiks themselves, who say they have little need of the electricity which is mostly exported to Afghanistan and other republics, seem in little doubt. A few days after the Spitak disaster, environmentalists and others formally petitioned for a halt to dam construction. 